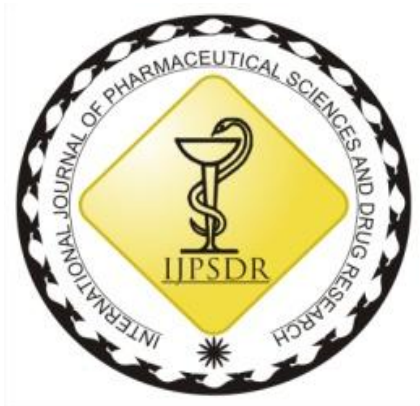

ISSN: 0975-248X

RESEARCH ARTICLE CODEN (USA): IJPSPP

$(\mathrm{cc})$ EY-NC-SA

\title{
A Structure Based Drug Designing of Bioactive Compounds of Gracilaria edulis against Virulent Bacterial Enzyme Aureolysin
}

\author{
Abhishek Biswal R, Vivek Pazhamalai* \\ Department of Bio-Engineering, School of Engineering, Vels Institute of Science, Technology and Advanced Studies \\ (VISTAS), Chennai, India
}

Copyright (C) 2019 Abhishek Biswal R et al. This is an open access article distributed under the terms of the Creative Commons AttributionNonCommercial-ShareAlike 4.0 International License which allows others to remix, tweak, and build upon the work non-commercially, as long as the author is credited and the new creations are licensed under the identical terms.

\begin{abstract}
The bioactive compounds of Gracilaria edulis were determined by using Gas Chromatography Mass spectroscopy. The drug compounds were screened for analyzing the inhibition potential against the virulent bacterial enzyme. In this research, the protein responsible for bacterial infection was docked against the drug compounds of Gracilaria edulis. The data of the virulent enzymes are studied and retrieved from PDB. The bioactive compounds were screened by Lipinski rule of five and ADMET properties. Using Autodock 4.2.6 the molecular docking analysis were done against virulent enzymes and was visualized by discovery studio 3.1. The bioactive compound eugenol with binding energy $-4.42 \mathrm{Kcal} / \mathrm{mol}$ followed by 2 Heptene, 2,4,4,6 tetramethyl $-3.89 \mathrm{Kcal} / \mathrm{mol}$ and 1, 2-Propanediol 2.77 $\mathrm{Kcal} / \mathrm{mol}$. The hydrogen and vanderwaals interaction of amino acids were studied. This research work mainly focuses on targeting the virulent enzymes that can reduce clinical costs by designing novel drug.
\end{abstract}

Keywords: Molecular docking, Gracilaria edulis, ADMET properties, Eugenol, Hydrogen and vanderwaals interaction.

DOI: 10.25004/IJPSDR.2019.110512

Int. J. Pharm. Sci. Drug Res. 2019; 11(5): 226-230

*Corresponding author: Mr. Vivek Pazhamalai

Address: Department of Bio-Engineering, School of Engineering, Vels Institute of Science, Technology and Advanced Studies (VISTAS), Chennai, India

E-mail $\bowtie$ : viveksncet2011@gmail.com

Relevant conflicts of interest/financial disclosures: The authors declare that the research was conducted in the absence of any commercial or financial relationships that could be construed as a potential conflict of interest.

Received: 22 July, 2019; Revised: 31 August, 2019; Accepted: 10 September, 2019; Published: 25 September, 2019

\section{INTRODUCTION}

Gracilaria edulis that comes under genus Rhodophyta serves as an edible food material for humans along with various species. The economic importance of red seaweed is agarophyte that contains numerous amount of agar. Gracilaria edulis (Wild) occurs in the Indian ocean (East Africa, Laccadive islands, India, Sri Lanka) and in the pacific ocean (China, Japan, Micronesia, north-eastern Australia). In South East Asia, it is found in Burma (Myanmar). In India, the Gracilariaceae represents twelve types of species. Of these, Gracilaria corticata commonly grows in intertidal zone on rocky part. This was recorded in India in scanty literature is available of this species. [1] In India, Gracilaria is confined to two regions of coasts. Studies on Gracilaria from the coast of south east India are mainly concentrated on localities of Madras, Mahabalipuram, Pamban, Mandapum, Tranquebar, Cape Comorin, Tuticorin, Krusadi and Andaman coasts. Geographically and ocenographically, the west coast region of India constitutes the long stretch of shore line between Karachi (Pakistan) and Cape Comorin (India). 
[2-3] The whole plant of G. edulis has excellent applications in medical and other fields. The red seaweed Gracilaria edulis contains various types of antimicrobial activities. This plant can be use to feed animals, as fertilizer for plants and also for water purification. The traditional use of this plant is to cure knee joints and to treat virulent microbes. [4] The biochemical characterization of carbohydrates, lipid and protein were done in Gracilaria edulis which shows the high presence of carbohydrate and protein. The quantitative analysis of phenol shows $250-300 \mathrm{mg} / \mathrm{ml}$, carbohydrate shows $200-160 \mu \mathrm{g} / \mathrm{ml}$. [5-6]

The whole plant was dried and used for various types of medical therapies. Gracilaria edulis mainly cures bacterial, fungal and diabetic diseases. Various types of extract like methanol, ethanol, chloroform, hexane, isoamyl alcohol and propanol were used for performing activities against Pseudomonas aeruginosa, Salmonella typhi, Klebsiella pneumonia and Staphylococcus aureus. The isoamyl alcohol shows better inhibition activity against Staphylococcus aureus with $20 \mu \mathrm{g} / \mathrm{ml}$, Salmonella typhi as $20 \mu \mathrm{g} / \mathrm{ml}$, Klebsiella pneumonia as $40 \mu \mathrm{g} / \mathrm{ml}$ and Pseudomonas aeruginosaas $20 \mu \mathrm{g} / \mathrm{ml}$. This plant shows good potential against various types of pathogenic infections. Gracilaria edulis also contains food grade agar utilized for thickening or stabilizing agent in food production industries. The whole plants involves in the treatment of constipation, thyroid disorders, enteritis and also for urinary infection. The red algae also have the quality to feed sea creatures like shrimps and fishes. Therefore the studies aimed to dock the virulent bacterial enzyme against the drug compounds determined from Gracilaria edulis. ${ }^{[7-8]}$

\section{MATERIALS ANS METHODS}

Determination of bioactive compounds from Gracilaria edulis by Gas Chromatography Mass Spectroscopy

Gracilaria edulis, which is mainly an edible plant, contains bioactive organic compounds. GCMS is carried out using the Shimadzu QP2000 A equipment. The phytoconstituents obtained from Gracilaria edulis are Phthalic acid, Nonane, 1,2-Propanediol, Sulfurous acid, Undecane, Eugenol and 2 Heptene 2,4,4,6 tetramethyl compounds reported by Abimannan et. al., 2018. [9] These compounds have the potential might play a major role for antibacterial and antioxidant activities. The major group of compounds consists of phenolic stretches, straight hydrocarbon and ester stretches. No reports are available for Gracilaria edulis against the virulent bacterial enzyme Aureolysin. The bioactive compounds were analyzed for its drug properties by docking against the virulent enzyme. The structure based ligand shows the potential docking interaction against the drug molecules. The active sites of the docked compound were visualized by visualize software. The Lipinski rule of five plays a major role in screening the drug ability. The rule comprises of five criteria namely $\log \mathrm{P}(< \pm 5.6)$, Number of hydrogen donors $(<10)$, Number of hydrogen donors $(<5)$, molecular weight $(<500)$ and molar refractivity $(40-130)$. It elucidate the drug likeness of a compound based on the consuming the drug orally. ${ }^{[10]}$

\section{Enzyme targets}

Enzyme Aureolysin (PDB Id: IBQB) is a drug target implemented for docking. The chain $\mathrm{A}$ is used for docking by removing the water molecules and heteroatoms. Confirmational search of the structure was done for predicting the chainusing discovery studio.

\section{Staphylococcus aureus Aureolysin enzyme}

Aureolysin is an extracellular metallopreoteinase enzyme for the pathogenic bacteria Staphylococcus aureus. The exact role of aureolysin in staphylococcal infections requires detailed investigation. The inhibitors a1-antichymotrypsin and a1-proteinase produced by aureolysin with direct proteolytic activation of prothrombin is responsible for Staphylococcal diseases. Aureolysin involves in the immunological reactionsby altering the stimulation of $\mathrm{B}$ and $\mathrm{T}$ lymphocytes by polyclonal activators which inhibits the immunoglobulin through lymphocytes. This enzyme consists of single chain with 301 amino acids. The active site coordinates inn zinc ion atoms are His144 and His 148 of helix a2, one carboxylate oxygen of Glu 168 at $C$ terminal sub domain as shown in Figure 1. The catalysticGlu 145 binds with the carboxylated zinc ions with single solvent system. Leu135, Phe132, Val141, Gly186, Met185 and Leu199 are the hydrophobic residues with substitute. The active site between $\mathrm{N}$ terminal and $C$ terminal contains deep and narrow cleft. This bacterium produces zinc dependent ion with metalloproteinase that exhibits several virulence diseases like Legionella pneumophila, Pseudomonas aeruginosa and Listeria monocytogenes. [11]
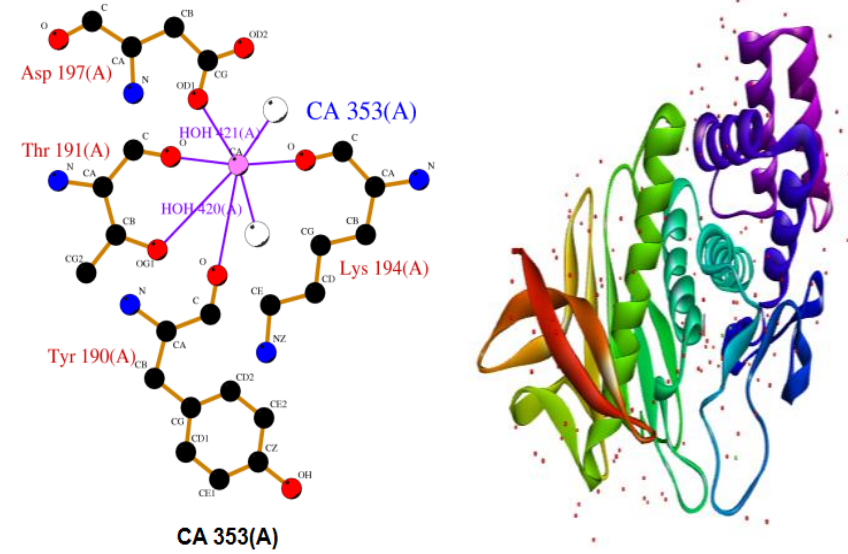

Fig. 1: Structure of Staphylococcus aureus side chain A

\section{Screening of drug compounds}

ADMET (Absorption Distribution Metabolism Excretion Toxicity) plays a major role in screening the drug likeness by analyzing the parameters of drug compounds. The drug compounds were tested for water solubility, gastro intestinal absorption, blood brain barrier, central nervous system and analyzing the 
dosage of human as well a rat. The evaluation was done by Swiss Institute of Bioinformatics (http://www.sib.swiss) to calculate the behaviour of drug with Lipophilicity. [12]

\section{Discovery studio 3.1visualizer}

This software is mainly used to visualize the interactions of docked images with conformational search. The 2D interactions and 3D interactions of the docking analysis will be visualized along with the surface image. The ligand interactions with amino acid coding that contains vanderwaals interaction and hydrogen bonding will be visualized in 2D interactions. The surface images were also visualized which shows the confirmations of structure based ligand docking against bacterial enzyme.

\section{RESULTS AND DISCUSSION}

The molecular docking analysis of each compound differentiates the binding energy and drug likeness against virulent bacterial enzymes. The bioactive compounds were subjected to Lipinski rule of five as shown in Table 1. As the plant is edible every compound satisfies the Lipinski rule of five. The compound sulfurous acid and 1, 2-propanediol have low lipophilicity that can be easily suitable for gastro intestinal absorption.

Table 1: Screening of compounds by Lipinski rule of five

\begin{tabular}{cccccc}
\hline $\begin{array}{c}\text { Compound } \\
\text { Name }\end{array}$ & Mass & $\begin{array}{c}\text { Hydrogen } \\
\text { bond } \\
\text { donor }\end{array}$ & $\begin{array}{c}\text { Hydrogen } \\
\text { bond } \\
\text { acceptor }\end{array}$ & LOGp & $\begin{array}{c}\text { Molar } \\
\text { Refractivity }\end{array}$ \\
\hline Eugenol & 164 & 1 & 2 & 2.12 & 48.55 \\
Nonane & 128 & 0 & 0 & 3.75 & 43.66 \\
Undecane & 156 & 0 & 0 & 4.53 & 52.90 \\
$\begin{array}{c}\text { 2 Heptene } \\
\text { 2,4,4,6 }\end{array}$ & 154 & 0 & 0 & 4.02 & 52.66 \\
tetramethyl & & & & & \\
$\begin{array}{c}\text { Sulfurous } \\
\text { acid }\end{array}$ & 82 & 2 & 2 & 0.56 & 13.13 \\
$\begin{array}{c}\text { Phthalic } \\
\text { acid }\end{array}$ & 166 & 2 & 4 & 1.08 & 40.36 \\
$\begin{array}{c}1,2- \\
\text { Propanediol }\end{array}$ & 76 & 2 & 2 & 0.76 & 18.78 \\
\hline
\end{tabular}

\section{ADMET properties}

The bioactive compounds were screened for ADMET properties which state the standard of the drug molecules present. The intestinal absorption parameters of the compound were observed which results the solubility of water in the intestine. The compound 2 Heptene 2,4,4,6 tetramethyl shows the least absorption of water solubility. The p- glycoprotein inhibitor and substrate have no response against the drug a shown in Table 2.

The distribution properties of the compounds were screened in which the blood brain barrier permeability shows the better result with less permeability. The central nervous system shows the negative result which means the compounds have poor permeability which was shown in Table 3.

The metabolism factor of cytochrome p450 was screened to metabolize potential toxic compounds. The compounds were screened for the drug likeness against the liver cells. The results were shown in Table 4 with both substrate and inhibitor of compounds.

The excretion and the toxicity of the compounds were screened by analyzing the dosage of the drug for human and rat. The hepatotoxicity level as well as skin sensitization level was checked which was shown in Table 5. The dosage level of each compound varies in which the compound 1,2-propanediol shows the highest dosage level in rat as well as human.

\begin{tabular}{|c|c|c|c|c|c|c|}
\hline $\begin{array}{l}\text { Compo } \\
\text { und } \\
\text { Name }\end{array}$ & $\begin{array}{c}\text { Water } \\
\text { solubi } \\
\text { lity } \\
(\text { log } \\
\text { mol/L) }\end{array}$ & $\begin{array}{c}\text { Caco2 } \\
\text { permeabil } \\
\text { ity (Log } \\
\text { Pabb in } \\
10^{-6} \\
\mathrm{~cm} / \mathrm{Sec}) \\
\end{array}$ & $\begin{array}{c}\text { GI } \\
\text { absorpt } \\
\text { ion (\%) }\end{array}$ & $\begin{array}{c}\text { Skin } \\
\text { permea } \\
\text { bility } \\
\text { (Log } \\
\text { Kp) }\end{array}$ & $\begin{array}{c}\text { P- } \\
\text { glycopr } \\
\text { otein } \\
\text { substra } \\
\text { te }\end{array}$ & $\begin{array}{c}\text { P- } \\
\text { glycopro } \\
\text { tein I } \\
\text { inhibitor }\end{array}$ \\
\hline Eugenol & -2.25 & 1.559 & 92.04 & -2.207 & No & No \\
\hline Nonane & -4.69 & 1.381 & 93.45 & -0.933 & No & No \\
\hline $\begin{array}{c}\text { Undeca } \\
\text { ne }\end{array}$ & -6.15 & 1.379 & 92.76 & -1.115 & No & No \\
\hline $\begin{array}{c}2 \\
\text { Hepten } \\
\text { e } 2,4,4,6 \\
\text { tetramet } \\
\text { hyl }\end{array}$ & -5.119 & 1.423 & 94.06 & -0.985 & No & No \\
\hline $\begin{array}{l}\text { Sulfuro } \\
\text { us acid }\end{array}$ & 0.859 & 1.803 & 87.69 & -2.77 & No & No \\
\hline $\begin{array}{l}\text { Phthalic } \\
\text { acid }\end{array}$ & -2.668 & 0.641 & 75.06 & -2.735 & No & No \\
\hline $\begin{array}{c}1,2- \\
\text { Propane } \\
\text { diol }\end{array}$ & 1.045 & 1.554 & 86.47 & -4.000 & No & No \\
\hline \multicolumn{7}{|c|}{ Table 3: Distribution criteria of bioactive compounds } \\
\hline $\begin{array}{l}\text { Compou } \\
\text { Name }\end{array}$ & & $\begin{array}{l}\text { VDss } \\
\text { (human) } \\
\text { (Log } \\
\text { L/kg) } \\
\end{array}$ & $\begin{array}{l}\text { Fraction } \\
\text { unbound } \\
\text { (human) } \\
(\mathrm{Fu})\end{array}$ & $\begin{array}{c}\text { BBB } \\
\text { permeabilit } \\
(\log B B)\end{array}$ & & $\begin{array}{c}\text { CNS } \\
\text { permeability } \\
\text { (Log PS) }\end{array}$ \\
\hline Eugen & & 0.24 & 0.251 & 0.374 & & -2.007 \\
\hline Nonan & & 0.425 & 0.357 & 0.807 & & -1.799 \\
\hline Undeca & & 0.537 & 0.247 & 0.844 & & -1.690 \\
\hline $\begin{array}{r}2 \text { Hepte } \\
2,4,4,6\end{array}$ & & 0.369 & 0.324 & 0.759 & & -1.711 \\
\hline \multicolumn{7}{|c|}{ tetramethyl } \\
\hline $\begin{array}{r}\text { Sulfuro } \\
\text { acid }\end{array}$ & & -0.923 & 0.808 & -0.469 & & -3.083 \\
\hline $\begin{array}{r}\text { Phthal } \\
\text { acid }\end{array}$ & & -1.775 & 0.497 & -0.038 & & -2.891 \\
\hline $\begin{array}{r}1,2- \\
\text { Propaned }\end{array}$ & & -0.341 & 0.824 & -0.302 & & -2.962 \\
\hline
\end{tabular}

\begin{tabular}{|c|c|c|c|c|c|c|c|}
\hline $\begin{array}{l}\text { Compou } \\
\text { nd } \\
\text { Name }\end{array}$ & $\begin{array}{c}\text { CYP2 } \\
\text { D6 } \\
\text { substr } \\
\text { ate } \\
\end{array}$ & $\begin{array}{c}\text { CYP3 } \\
\text { A4 } \\
\text { substr } \\
\text { ate } \\
\end{array}$ & $\begin{array}{c}\text { CYP1 } \\
\text { A2 } \\
\text { inhibi } \\
\text { tor } \\
\end{array}$ & $\begin{array}{c}\text { CYP2 } \\
\text { C19 } \\
\text { inhibi } \\
\text { tor } \\
\end{array}$ & $\begin{array}{c}\text { CYP2 } \\
\text { C9 } \\
\text { inhibi } \\
\text { tor }\end{array}$ & $\begin{array}{c}\text { CYP2 } \\
\text { D6 } \\
\text { inhibi } \\
\text { tor } \\
\end{array}$ & $\begin{array}{c}\text { CYP3 } \\
\text { A4 } \\
\text { inhibi } \\
\text { tor }\end{array}$ \\
\hline Eugenol & No & No & Yes & No & No & No & No \\
\hline Nonane & No & No & No & No & No & No & No \\
\hline $\begin{array}{l}\text { Undeca } \\
\text { ne }\end{array}$ & No & No & No & No & No & No & No \\
\hline $\begin{array}{c}2 \\
\text { Heptene } \\
2,4,4,6 \\
\text { tetramet } \\
\text { hyl }\end{array}$ & No & No & No & No & No & No & No \\
\hline $\begin{array}{c}\text { Sulfurou } \\
\text { s acid }\end{array}$ & No & No & No & No & No & No & No \\
\hline $\begin{array}{l}\text { Phthalic } \\
\text { acid }\end{array}$ & No & No & No & No & No & No & No \\
\hline $\begin{array}{c}1,2- \\
\text { Propane } \\
\text { diol }\end{array}$ & No & No & No & No & No & No & No \\
\hline
\end{tabular}


Abhishek Biswal R et al. / A Structure Based Drug Designing of Bioactive Compounds of Gracilaria edulis.

Table 5: Excretion and Toxicity criteria of bioactive compounds

\begin{tabular}{|c|c|c|c|c|c|c|c|c|}
\hline $\begin{array}{l}\text { Compound } \\
\text { Name }\end{array}$ & $\begin{array}{c}\text { Renal OCT2 } \\
\text { substrate }\end{array}$ & $\begin{array}{l}\text { AMES } \\
\text { toxicity }\end{array}$ & $\begin{array}{c}\text { Max. tolerated } \\
\text { dose (human) } \\
\text { (Log mg/kg/day) }\end{array}$ & $\begin{array}{l}\text { hERG I } \\
\text { inhibitor }\end{array}$ & $\begin{array}{c}\text { Oral Rat Acute } \\
\text { Toxicity (LD50) } \\
\text { (mol/kg) }\end{array}$ & $\begin{array}{c}\text { Oral Rat Chronic } \\
\text { Toxicity (LOAEL) } \\
\text { (Log mg/kg) }\end{array}$ & $\begin{array}{c}\text { Liver } \\
\text { Toxicity }\end{array}$ & $\begin{array}{c}\text { Skin } \\
\text { Sensitisation }\end{array}$ \\
\hline Eugenol & No & Yes & 1.024 & No & 2.118 & 2.049 & No & Yes \\
\hline Nonane & No & No & 0.549 & No & 1.683 & 2.528 & No & No \\
\hline Undecane & No & No & 0.389 & No & 1.597 & 2.698 & No & Yes \\
\hline $\begin{array}{l}2 \text { Heptene } 2,4,4,6 \\
\text { tetramethyl }\end{array}$ & No & No & 0.667 & No & 1.658 & 2.565 & No & Yes \\
\hline Sulfurous acid & No & No & 1.394 & No & 1.963 & 2.594 & No & No \\
\hline Phthalic acid & No & No & 0.582 & No & 1.449 & 2.165 & No & No \\
\hline 1,2-Propanediol & No & No & 1.736 & No & 1.606 & 2.708 & No & No \\
\hline
\end{tabular}

Table 6: Docking confirmation of bioactive compounds of Gracilaria edulis

\begin{tabular}{|c|c|c|c|c|c|}
\hline $\begin{array}{c}\text { Compound } \\
\text { Name }\end{array}$ & $\begin{array}{l}\text { Binding } \\
\text { energy }\end{array}$ & $\begin{array}{c}\text { Vanderwaals } \\
\text { Interaction } \\
\end{array}$ & $\begin{array}{c}\text { No. of hydrogen } \\
\text { bonds }\end{array}$ & $\begin{array}{c}\text { Hydrogen } \\
\text { interactions }\end{array}$ & Total no of residues \\
\hline Eugenol & -4.42 & $\begin{array}{c}\text { ALA 116, ASN 114, GLU 145, VAL } \\
\text { 414, HIS 144, MET 185, LEU 199, } \\
\text { ARG 200, HIS 148, TYR 159, GLU } \\
168\end{array}$ & 2 & HIS 228, ALA 115 & $\begin{array}{l}\text { ALA 116, ASN 114, GLU 145, } \\
\text { VAL 414, HIS 144, MET 185, LEU } \\
\text { 199, ARG 200, HIS 148, TYR 159, } \\
\text { GLU } 168\end{array}$ \\
\hline Nonane & -2.71 & $\begin{array}{l}\text { TRP 117, ALA 115, ALA 116, GLU } \\
\text { 145, ARG 200, HIS 148, LEU 199, } \\
\text { VAL 141, MET 185, HIS 144, HIS } \\
\text { 228, GLU 168, TYR } 159\end{array}$ & 0 & 0 & $\begin{array}{l}\text { TRP 117, ALA 115, ALA 116, } \\
\text { GLU 145, ARG 200, HIS 148, LEU } \\
\text { 199, VAL 141, MET 185, HIS 144, } \\
\text { HIS 228, GLU 168, TYR } 159\end{array}$ \\
\hline Undecane & -2.77 & $\begin{array}{c}\text { VAL 141, GLU 145, MET 185, ARG } \\
\text { 200, LEU 199, HIS 148, TRP 117, } \\
\text { ALA 116, HIS 228, ALA 115, ASN } \\
\text { 114, HIS } 144\end{array}$ & 0 & 0 & $\begin{array}{l}\text { VAL 141, GLU 145, MET 185, } \\
\text { ARG 200, LEU 199, HIS 148, TRP } \\
\text { 117, ALA 116, HIS 228, ALA 115, } \\
\text { ASN 114, HIS } 144\end{array}$ \\
\hline $\begin{array}{l}2 \text { Heptene } 2,4,4,6 \\
\text { tetramethyl }\end{array}$ & -3.89 & $\begin{array}{l}\text { ALA 116, ASN 114, HIS 148, ALA } \\
\text { 115, ARG 200, HIS 228, HIS 144, } \\
\text { LEU 44, LEU 199, MET 185, VAL } \\
\text { 141, GLU 145, TYR } 159\end{array}$ & 0 & 0 & $\begin{array}{l}\text { ALA 116, ASN 114, HIS 148, } \\
\text { ALA 115, ARG 200, HIS 228, HIS } \\
\text { 144, LEU 44, LEU 199, MET 185, } \\
\text { VAL 141, GLU 145, TYR } 159\end{array}$ \\
\hline Sulfurous acid & -3.82 & $\begin{array}{c}\text { HIS 228, LEU 145, LEU 148, GLU } \\
\text { 145, VAL 141, TYT } 148\end{array}$ & 0 & 0 & $\begin{array}{c}\text { HIS 228, LEU 145, LEU 148, GLU } \\
\text { 145, VAL 141, TYT } 148\end{array}$ \\
\hline Phthalic acid & -0.50 & $\begin{array}{c}\text { HIS 148, LEU 199, ASN 114, ALA } \\
\text { 115, VAL 141, HIS } 144\end{array}$ & 4 & $\begin{array}{l}\text { MET 185, GLU 168, } \\
\text { ARG 200, HIS } 228\end{array}$ & $\begin{array}{l}\text { MET 185, GLU 168, ARG 200, } \\
\text { HIS 228, HIS 148, LEU 199, ASN } \\
\text { 114, ALA 115, VAL 141, HIS } 144\end{array}$ \\
\hline 1,2-Propanediol & -2.88 & GLU 145, HIS 144, HIS 228 & 4 & $\begin{array}{l}\text { TYR 159, GLU } 168, \\
\text { ARG 200, HIS } 148\end{array}$ & $\begin{array}{l}\text { TYR 159, GLU 168, ARG 200, HIS } \\
\text { 148, GLU 145, HIS 144, HIS } 228\end{array}$ \\
\hline
\end{tabular}
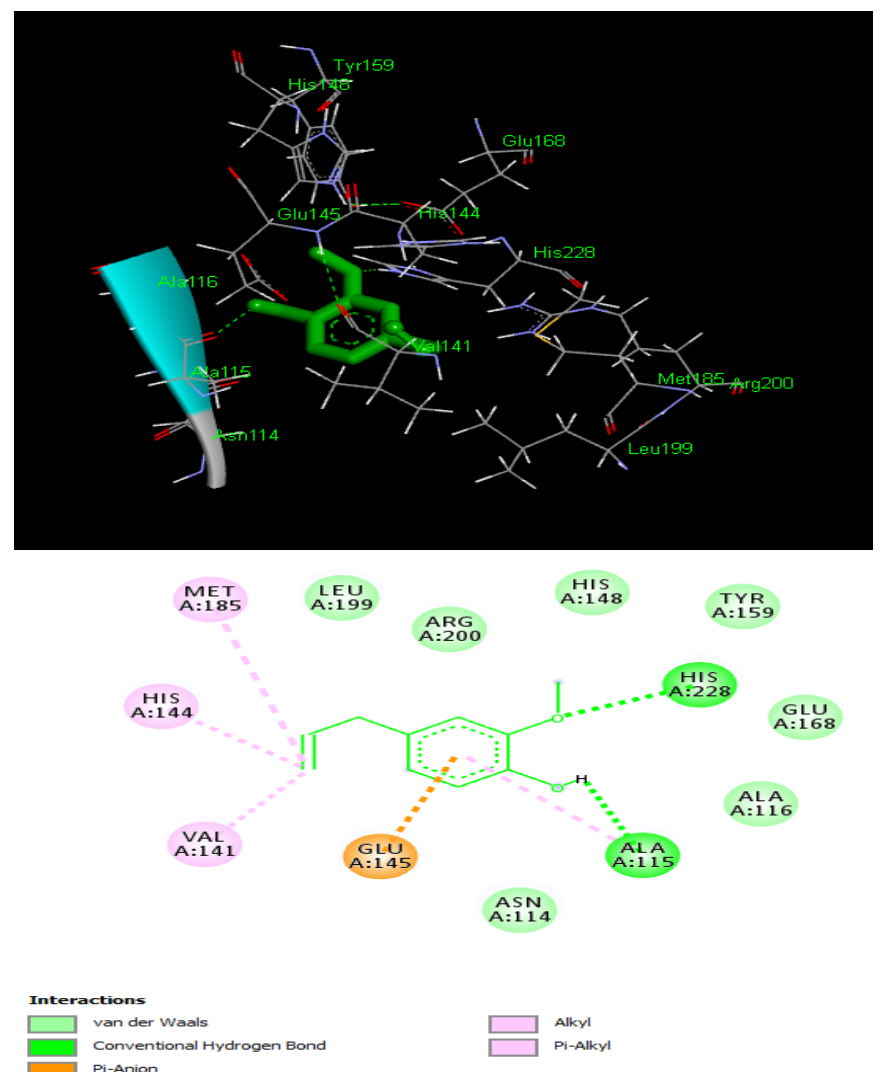

Fig. 2: 2D and 3D interactions of Eugenol against virulent enzyme

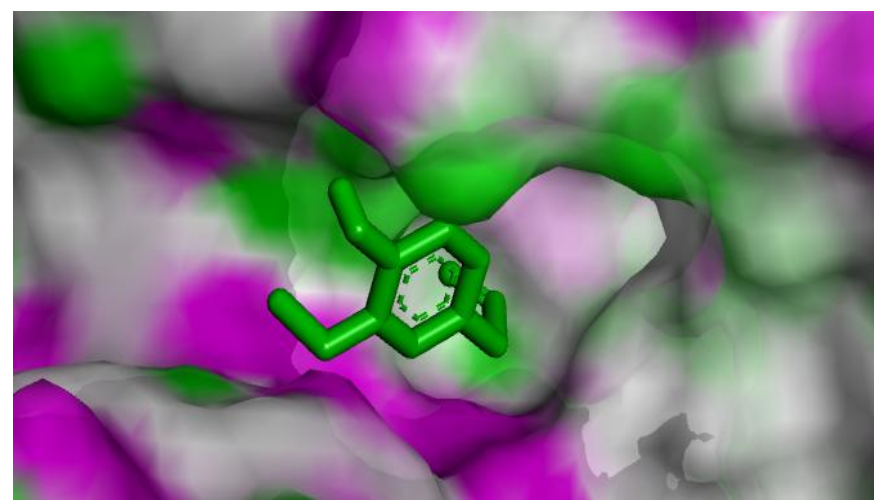

Fig. 3: Conformational surface interaction of eugenol

All the compounds encouraged the binding strategies among the virulent protein target. The best docking score observed was in eugenol at $-4.42 \mathrm{Kcal} / \mathrm{mol}$. The interaction shows the better hydrogen interactions with 2 bond formation and the hydrogen interaction amino acids are HIS 228, ALA 115 followed by 2 Heptene 2,4,4,6 tetramethyl with binding score $-3.89 \mathrm{Kcal} / \mathrm{mol}$. The maximum hydrogen interactions were found in Phthalic acid and 1,2-Propanediol. The compound named eugenol exhibit inhibitory activity when compared to standard drug. The standard drug used here is vancomycin with binding score -+2.78. The docking studies also imply that the amino acids ASP, 
THR, TYR LEU have better binding interactions. These studies will illustrate the novel drug design against the virulent bacterial enzymes as shown in Table 6 and Figure 2-4. These drug compounds imply the action of novel drug antibiotic that target the Aureolysin from staphylococcus aureus.
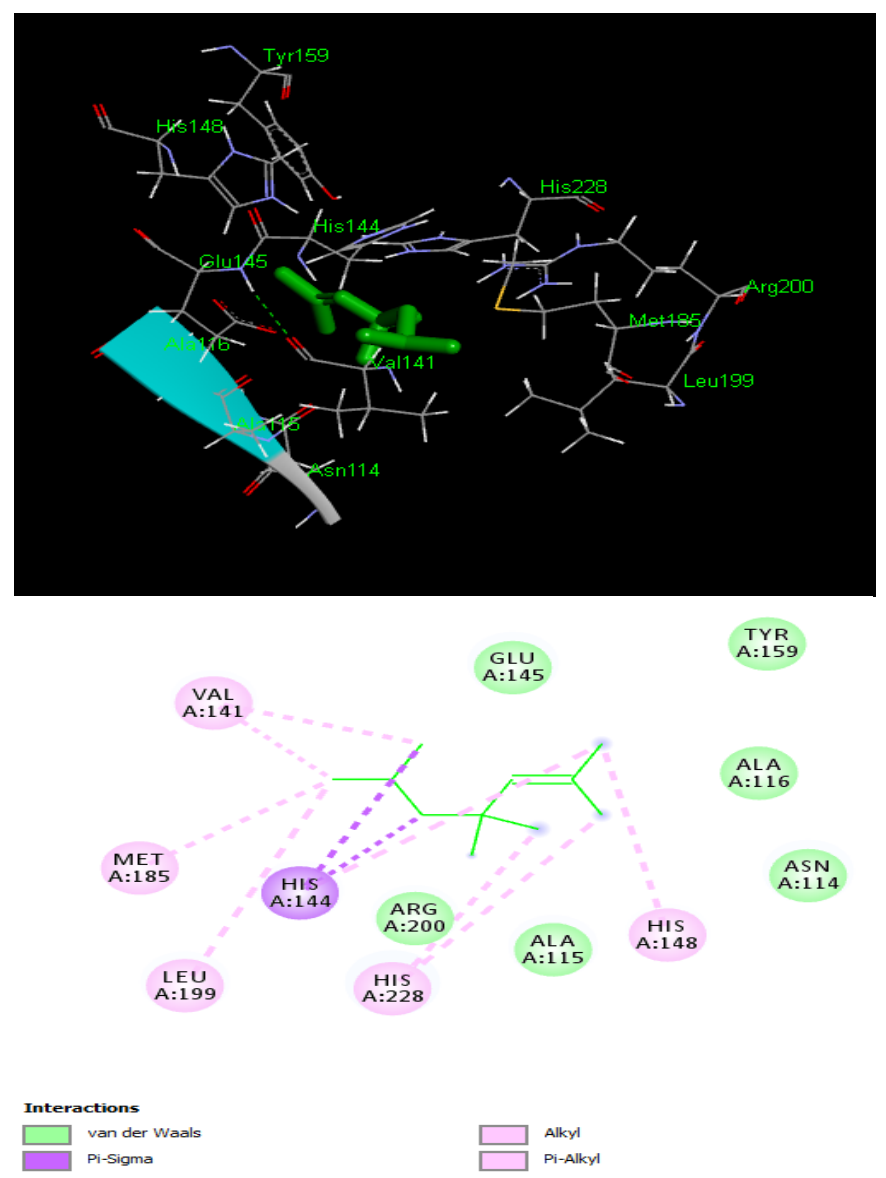

Fig. 4: 2D and 3D interactions of 2 Heptene 2,4,4,6 tetramethyl against virulent enzymes

Gracilaria edulis, traditionally used as aayurvedic medicine against several diseases. This plant also used for feeding animals. This study mainly reveals the activity of drug compounds against virulent enzymes. The drug compounds were subjected for Lipinski rule of five and ADMET properties. The bioactive compounds of Gracilaria edulis has the ability to use as a drug molecule. The eugenol compound with binding energy $-4.42 \mathrm{Kcal} / \mathrm{mol}$ shows better drug potential against than the control docking. Thus the bioactive compounds show the better results that lead to novel drug discovery. The bioactive compounds inhibits the virulent enzymes of Staphylococcus aureus with better docking properties. The docking analysis provides a detailed confirmation for designing a novel drug molecule.

\section{ACKNOWLEDGEMENT}

We sincerely thank Vels Institute of science Technology and Advanced Studies for their support toward the completion for our research work.

\section{REFERENCES}

1. Chennubhotla VS, Kaliaperumal N, Kalimuthu S. Culture of Gracilaria edulis in the inshore waters of Gulf of Mannar (Mandapam). Indian Journal of Fisheries. 1978;25(1\&2):228-9.

2. Chennubhotla VS, Kaliaperumal N, Ramalingam JR, Kalimuthu S. Growth, reproduction and spore output in Gracilaria foliifera (Forsskal) Boergesen and Gracilariopsis sjoestedtii (Kylin) Dawson around Mandapam. Indian Journal of Fisheries. 1986;33(1):76-84.

3. Kolanjinathan K, Saranraj P. Pharmacological efficacy of marine seaweed Gracilaria edulis extracts against clinical pathogens. Global Journal of Pharmacology. 2014;8(2):268-74.

4. Arulkumar A, Rosemary T, Paramasivam S, Rajendran RB. Phytochemical composition, in vitro antioxidant, antibacterial potential and GC-MS analysis of red seaweeds (Gracilaria corticata and Gracilaria edulis) from Palk Bay, India. Biocatalysis and agricultural biotechnology. 2018 Jul 1;15:6371

5. Sakthivel R, Muniasamy S, Archunan G, Devi KP. Gracilaria edulis exhibit antiproliferative activity against human lung adenocarcinoma cell line A549 without causing adverse toxic effect in vitro and in vivo. Food \& function. 2016;7(2):1155-65.

6. De Almeida CL, Falcão DS, Lima DM, Gedson R, Montenegro DA, Lira NS, Athayde-Filho D, Petrônio F, Rodrigues LC, De Souza MD, Barbosa-Filho JM. Bioactivities from marine algae of the genus Gracilaria. International journal of molecular sciences. 2011 Jul;12(7):4550-73.

7. Sivanandhan G, Arunachalam C, Selvaraj N, Sulaiman AA, Lim YP, Ganapathi A. Expression of important pathway genes involved in withanolides biosynthesis in hairy root culture of Withania somnifera upon treatment with Gracilaria edulis and Sargassum wightii. Plant Physiology and Biochemistry. 2015 Jun 1;91:61-4.

8. Eahamban K, Marimuthu J. Preliminary phytochemical, UVVIS, HPLC and anti-bacterial studies on Gracilaria corticata J. Ag. Asian Pacific Journal of Tropical Biomedicine. 2012 Feb 1;2(2):S568-74.

9. Bhal SK, Kassam K, Peirson IG, Pearl GM. The Rule of Five revisited: applying $\log \mathrm{D}$ in place of $\log \mathrm{P}$ in drug-likeness filters. Molecular pharmaceutics. 2007 Aug 6;4(4):556-60.

10. Banbula A, Potempa J, Travis J, Fernandez-Catalén C, Mann K, Huber R, Bode W, Medrano FJ. Amino-acid sequence and three-dimensional structure of the Staphylococcus aureus metalloproteinase at $1.72 \AA$ resolution. Structure. 1998 Sep 15;6(9):1185-93.

11. da Silva $\mathrm{CH}$, Campo VL, Carvalho I, Taft CA. Molecular modeling, docking and ADMET studies applied to the design of a novel hybrid for treatment of Alzheimer's disease. Journal of molecular graphics and modelling. 2006 Oct 1;25(2):169-75.

12. Biswal AR, Mirunalini K, Jayshree P, Pazhamalai V. Molecular Docking Analysis of Bioactive Compounds of Acacia concinna against Fungal Protein. Journal of Pharmaceutical Sciences and Research. 2019 Apr 1;11(4):121622.

HOW TO CITE THIS ARTICLE: Biswal RA, Pazhamalai V. A Structure Based Drug Designing of Bioactive Compounds of Gracilaria edulis against Virulent Bacterial Enzyme Aureolysin. Int. J. Pharm. Sci. Drug Res. 2019; 11(5): 226-230. DOI: 10.25004/IJPSDR.2019.110512 